\title{
RANCANGAN SISTEM INFORMASI PENGGAJIAN PADA PERUSAHAAN JASA BENGKEL
}

\author{
Angelina Permatasari; Lianawati Cristian \\ Jurusan Komputerisasi Akuntansi, Fakultas Ilmu Komputer, Universitas Bina Nusantara, \\ Jln. K.H. Syahdan No. 9, Palmerah Jakarta Barat 11480 \\ Telp : (021) 5345830, 5350660 Fax : (021) 5300244 \\ angelina_psw@binus.ac.id ${ }^{1}$; liana_ch1309@binus.ac.id ${ }^{2}$
}

\begin{abstract}
The aim of the research is to analyze existing problems on companies in the automotive service industry, namely, analyzing the current payroll system, identifying needs, and modify and design a better payroll system accordingly. Methods used are analysis methods and design methods. Analysis methods conducted are literature study, field observation, survey on current system, needs analysis survey, identifying information needs, interview, and design methods used is Object Oriented Analysis and Design (OOAD). Obtained results are improved payroll system which has been done manually before. It can be concluded that a computerized payroll information system can solve existing problems and old procedures.
\end{abstract}

Keywords: design, payroll accounting information system, object oriented analysis and design (OOAD)

\begin{abstract}
ABSTRAK
Tujuan penelitian ini adalah untuk menganalisis masalah-masalah yang ada pada perusahaan yang bergerak dibidang jasa bengkel, mengenai sistem informasi akuntansi penggajian yang sedang berjalan, mengidentifikasi kebutuhan informasi, memperbaiki dan merancang sistem informasi penggajian untuk perusahaan ini. Metodologi yang digunakan adalah metode analisis dan metode perancangan. Metode analisis yang dilakukan pada penelitian ini adalah studi pustaka, teknik observasi, survey terhadap sistem lama, survey analisis kebutuhan, identifikasi kebutuhan informasi, wawancara, sedangkan metode perancangan adalah menggunakan Object Oriented Analysis and Design (OOAD). Hasil yang dicapai adalah berupa perbaikan sistem informasi penggajian yang selama ini dilakukan secara manual. Sistem informasi penggajian yang terkomputerisasi dapat memecahkan masalah - masalah yang terjadi pada sistem dan prosedur yang lama.
\end{abstract}

Kata kunci : Perancangan, Sistem Informasi Akuntansi Penggajian, Object Oriented Analysis and Design $(O O A D)$ 


\section{PENDAHULUAN}

\section{Latar Belakang}

Di dalam suatu perusahaan seringkali terjadi permasalahan dalam kegiatan rutinitas yang dilakukan seperti kesalahan pencatatatan data, redudansi, kesalahan dalam perhitungan data, demikian pula dalam hal update data perusahaan. Hal ini bisa menimbulkan banyak kerugian bagi perusahaan tersebut seperti mengakibatkan keterlambatan dalam pelaporan, kesalahan dalam pengelolaan keuangan ataupun kesalahan dalam pengambilan keputusan.

Banyak dari perusahaan yang mengalami hal seperti diatas menggunakan Sistem Informasi yang telah terkomputerisasi untuk menyelesaikan permasalahan-permasalahan tersebut. Namun terkadang perusahaan mengartikannya terbatas hanya dengan menggunakan sistem dimana sebenarnya sistem tersebut kurang memadai untuk menyelesaikan semua permasalahan yang dihadapi.

Studi kasus penelitian ini pada perusahaan yang bergerak dalam bidang jasa bengkel mobil. Perusahaan ini termasuk perusahaan jasa yang melayani perbaikan atau service mobil bagi perorangan maupun perusahaan-perusahaan, dimana masih menggunakan Sistem Informasi yang kurang memadai karena tidak memiliki sarana yang diperlukan untuk mengatasi permasalahan yang telah terjadi dalam perusahaan terutama masalah perhitungan gaji. Dalam melakukan perhitungan gaji karyawannya perusahaan masih menggunakan sistem manual, sehingga terkadang mengakibatkan adanya kesalahan dalam perhitungan, dan keterlambatan gaji yang dibayarkan. Perusahaan ini memperkerjakan 30 orang karyawan.

Kajian teori mengenai penggajian, menurut Mulyadi (2001: 373), gaji adalah pembayaran atas penyerahan jasa yang dilakukan oleh karyawan yang dibayarkan secara tetap per bulan.

Ruang lingkup yang akan dibahas lebih lanjut meliputi beberapa hal seperti perhitungan absensi karyawan, perhitungan tunjangan karyawan, perhitungan lembur karyawan, perhitungan gaji karyawan setiap bulan, menghasilkan slip gaji karyawan, laporan kehadiran karyawan, laporan gaji karyawan. Untuk pajak penghasilan ditanggung oleh perusahaan sehingga tidak mengurangi penghasilan karyawan. Perancangan sistem informasi penggajian secara komputerisasi menggunakan database Ms.Access 2007 dan program Borland Delphi versi 5.

Tujuan dari penelitian ini adalah mengidentifikasi sejauh mana sistem informasi penggajian dapat bermanfaat bagi perusahaan, menganalisis masalah yang ada pada sistem perusahaan, dan merancang sistem informasi penggajian pada perusahaan ini.

Manfaat dari penelitian ini adalah dapat mengetahui kekurangan dan kelemahan yang ada pada sistem yang sedang berjalan sehingga dapat diatasi sebelum mengakibatkan kesalahan perhitungan gaji karyawan ataupun kesalahan dalam pelaporan, memberikan informasi yang benar dan tepat waktu kepada pihak manajemen dalam pengambilan keputusan yang terbaik sehingga penelitian ini dapat berguna bagi perusahaan dalam meningkatkan efektifitas dan efisiensi dalam siklus penggajian.

\section{METODE}

Metode yang digunakan adalah sebagai berikut. Pertama, metode analisis yaitu studi pustaka, teknik observasi, survey terhadap sistem lama, analisis kebutuhan, identifikasi kebutuhan informasi, wawancara. Kedua, metode perancangan adalah menggunakan Object Oriented Analysis and Design 
$(O O A D)$ yang dimulai dengan pembuatan rich picture, event table, entity relationship diagram, use case diagram, overview activity diagram, rancangan database, rancangan layar, rancangan laporan.

\section{Teori Pendukung}

Perancangan sistem adalah menuangkan suatu keadaan (input, proses dan output) yang ada pada sistem ke dalam suatu model tertentu. Model ini nantinya menggambarkan sistem yang ditinjau. (Haryanto, 2004:13)

Sistem informasi adalah suatu pengelolaan yang berarti mengumpulkan, memasukkan, mengolah data dan menyimpan, mengelola data, mengendalikan data dan pelaporan informasi sehingga organisasi dapat mencapai tujuan dan sasaran. (O’Brien et al, 2006: 28)

Pengertian database yang paling sederhana adalah kumpulan dari tabel. Satu tabel merepresentasikan suatu entitas tertentu dan suatu entitas terdiri atas beberapa atribut. Salah satu manfaat database adalah untuk memudahkan dalam mengakses data. Kemudahan pengaksesan data ini adalah sebagai implikasi dari keteraturan data yang merupakan syarat mutlak dari suatu database yang baik. (Haryanto, 2004: 5)

Object-Oriented Analysis and Design adalah sekumpulan petunjuk umum untuk membuat analisis dan desain. (Mathiassen et al, 2000: 12). Use Case Diagram adalah sekumpulan daftar dari use case yang terjadi dalam suatu aplikasi dan itu menandakan bahwa seorang aktor bertanggungjawab untuk masing-masing use case yang ada (Jones dan Rama, 2006: 267)

Database Relasional adalah suatu database yang di dalamnya terdapat tabel-tabel yang saling berelasi satu sama lain. (Haryanto, 2004: 8). Entity Relationship Diagram atau Diagram Hubungan Antar Entitas merupakan hasil akhir dari proses analisis terhadap sistem yang ditinjau yang dilakukan oleh seorang Analis Sistem (Haryanto, 2004: 12).

Gaji adalah pembayaran atas penyerahan jasa yang dilakukan oleh karyawan yang dibayarkan secara tetap perbulan. (Mulyadi, 2001: 373). Sedangkan Horngren, Harrison dan Bamber (2002: 430), berpendapat bahwa gaji merupakan pendapatan yang jumlahnya dihitung per tahun, per bulan atau per minggu. Gaji biasanya digunakan untuk pembayaran atas jasa manajerial, administratif dan jasa-jasa yang sama. Tarif gaji biasanya diekspresikan dalam periode bulan atau bulanan. (Warren, Reeve dan Fess, 2002: 446)

"Payroll plays an important part in the life of the business. Employees expect to be paid on time, and error-free. They assume that taxes and other payroll deductions will be calculated and deducted correctly from their gross pay. In other words, in addition to meeting the cost of each payroll, employers also must deposit state and federal income taxes, social security and medicare payments accurately and on time with the appropriate agencies.” Richard Mou, Brian Kleiner (2006: 284)

\section{HASIL DAN PEMBAHASAN}

\section{Sistem Penggajian Yang Sedang Berjalan}

Sistem informasi penggajian pada perusahaan yang bergerak dalam perusahaan jasa bengkel untuk perbaikan atau servis mobil ini masih dilakukan secara manual. Sampai saat ini kegiatan bisnis utama yang dijalankan adalah menerima jasa perbaikan mobil untuk perusahaan-perusahaan ataupun 
perorangan. Karyawan yang terlibat ada 30 orang, terdiri dari beberapa jabatan yaitu direktur, manajer, akuntansi, kasir, senior teknisi , yunior teknisi, sekretaris, SDM, customer service, cleaning service. Jika perbaikan mobil sedang banyak maka teknisi dan beberapa bagian perlu lembur untuk menyelesaikan perbaikan mobil tersebut.

\section{Rich Picture Prosedur Penggajian}

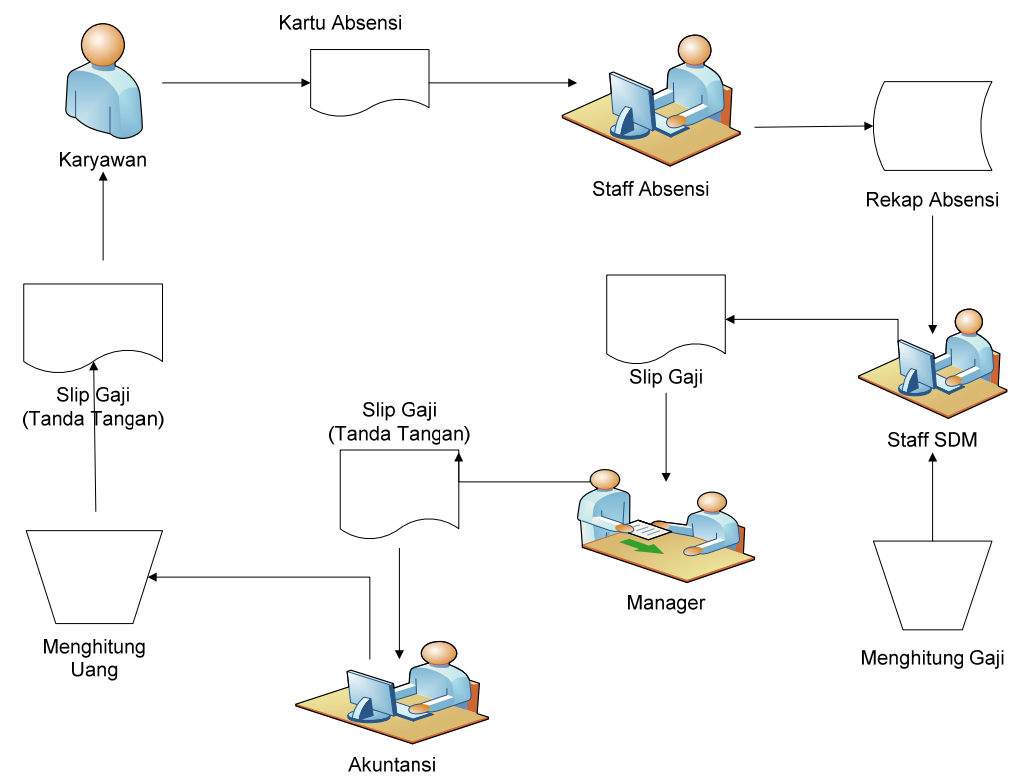

Gambar 1. Rich Picture Prosedur Penggajian

\section{Keterangan gambar 1}

1. Karyawan setiap hari akan melakukan absensi kehadiran

2. Bagian staff absensi akan mencatat kehadiran karyawan setiap hari

3. Setiap tanggal 25 bagian staff penggajian (SDM) akan melakukan perhitungan secara manual, berdasarkan dokumen absensi karyawan, daftar gaji pokok, tunjangan jabatan, tunjangan anak, tunjangan anak, tunjangan uang makan, asuransi, lembur.

4. Setelah selesai slip gaji yang sudah dibuat diserahkan ke manajer SDM untuk diperiksa

5. Setelah manajer menandatangani slip gaji, maka slip gaji tersebut diserahkan kepada bagian akuntansi untuk disiapkan uangnya.

6. Pada akhir bulan slip gaji dan uang akan diserahkan kepada karyawan.

\section{Formulir dan laporan pada sistem lama :}

Kartu absensi, Laporan Gaji Karyawan, Slip Gaji, Daftar Hadir Karyawan.

\section{Analisis temuan survey :}

1. Rekap absensi masih dilakukan secara manual oleh staff absensi

2. Ketidakakuratan dalam perhitungan gaji yang diterima setiap bulan

3. Dalam perhitungan lembur masih dilakukan manual

4. Tidak adanya pengawasan terhadap pencetakan salinan laporan atau rekap.

\section{Identifikasi Kebutuhan Informasi}

Informasi yang dibutuhkan oleh perusahaan antara lain: 
1. Laporan Kehadiran Karyawan.

2. Informasi slip gaji karyawan

3. Informasi Gaji Karyawan Bulanan.

4. Informasi Daftar Pegawai.

\section{Perancangan Sistem :}

\section{Event Table Sistem Informasi Penggajian Yang Diusulkan}

\begin{tabular}{|c|c|c|c|}
\hline Event & $\begin{array}{l}\text { Internal Agent } \\
\quad \text { Assuming } \\
\text { Responsibility } \\
\end{array}$ & Starts When & Activities in the event \\
\hline $\begin{array}{l}\text { Melakukan } \\
\text { pencatatan hari kerja }\end{array}$ & Staff Absensi & $\begin{array}{l}\text { Mengambil kartu absensi } \\
\text { dari tiap departement }\end{array}$ & $\begin{array}{l}\text { Meng-entry ke daftar absen } \\
\text { ke komputer }\end{array}$ \\
\hline Mengisi form & Staff SDM & $\begin{array}{l}\text { Pada awal sistem informasi } \\
\text { penggajian diterapkan }\end{array}$ & $\begin{array}{l}\text { Meng-entry form jabatan, } \\
\text { form golongan, form gaji } \\
\text { pokok, form pegawai }\end{array}$ \\
\hline $\begin{array}{l}\text { Menghitung Gaji } \\
\text { bulanan }\end{array}$ & Staff SDM & $\begin{array}{l}\text { Menerima rekap hari kerja } \\
\text { karyawan }\end{array}$ & $\begin{array}{l}\text { Mencetak slip gaji } \\
\text { karyawan }\end{array}$ \\
\hline $\begin{array}{l}\text { Menandantangani slip } \\
\text { gaji }\end{array}$ & Manager SDM & $\begin{array}{l}\text { Menerima slip gaji dari } \\
\text { staff SDM }\end{array}$ & $\begin{array}{l}\text { Memeriksa slip gaji } \\
\text { karyawan }\end{array}$ \\
\hline $\begin{array}{l}\text { Menarik uang di } \\
\text { Bank }\end{array}$ & Kasir & $\begin{array}{l}\text { Menerima Surat Perintah } \\
\text { Pengeluaran Uang (SPPU) }\end{array}$ & $\begin{array}{l}\text { Mengisi form Surat Perintah } \\
\text { Pengeluaran Uang (SPPU), } \\
\text { menarik uang di Bank, } \\
\text { menyerahkan slip penarikan } \\
\text { tunai ke Manager } \\
\text { Akuntansi, menyerahkan } \\
\text { uang ke Manajer SDM }\end{array}$ \\
\hline $\begin{array}{l}\text { Melakukan } \\
\text { pembayaran }\end{array}$ & Manajer SDM & $\begin{array}{l}\text { Menerima uang dan rekap } \\
\text { Gaji }\end{array}$ & $\begin{array}{l}\text { Memasukkan uang ke dalam } \\
\text { amplop sesuai dengan slip } \\
\text { Gaji yang ada, membagikan } \\
\text { Gaji kepada karyawan. }\end{array}$ \\
\hline
\end{tabular}

Gambar 2. Event Table Sistem Informasi Penggajian Yang Diusulkan

\section{Relantionship Database sistem Informasi Penggajian Yang Diusulkan}

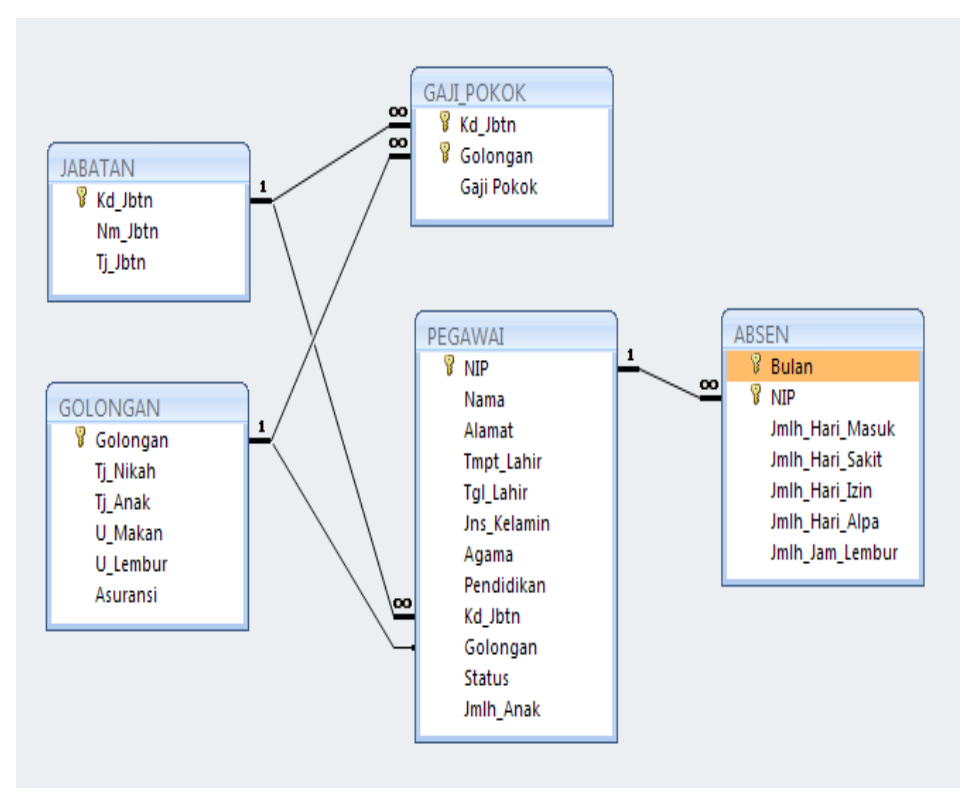


Gambar 3. Relationship Database Sistem Informasi Penggajian yang diusulkan Use Case Diagram Sistem Informasi Penggajian Yang Diusulkan

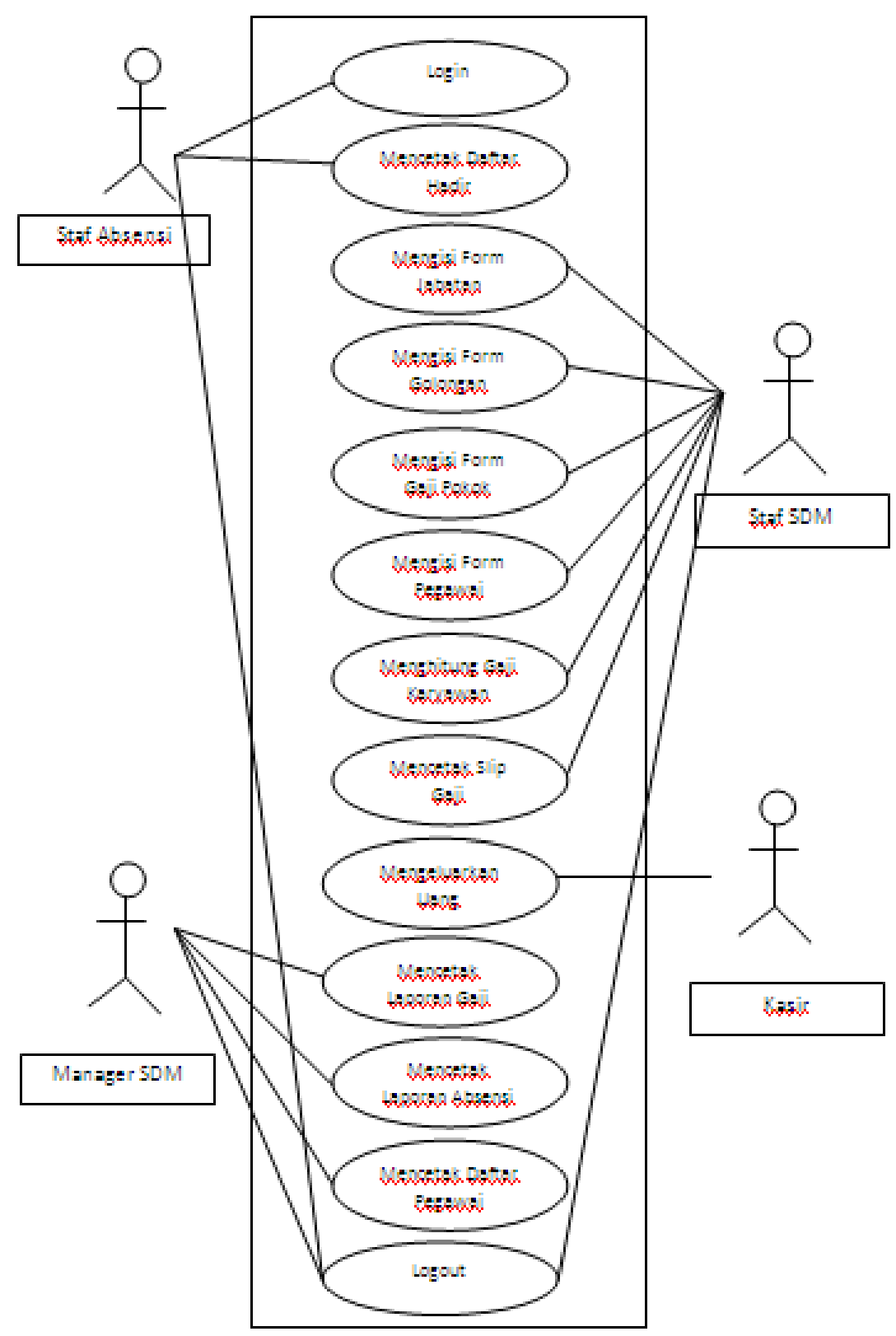

Gambar 4. Use Case Diagram Sistem Informasi Penggajian Yang Diusulkan

\section{Rancangan Database}

\section{Tabel Jabatan}

\begin{tabular}{|c|c|c|c|}
\hline Field Name & Data Type & Field Size & Description \\
\hline Kd_Jbtn & text & 5 & $\begin{array}{l}\text { Kode Jabatan } \\
\text { Primary key untuk Tabel Jabatan }\end{array}$ \\
\hline Nm_Jbtn & $\begin{array}{c}\text { text } \\
\text { number }\end{array}$ & $\begin{array}{c}25 \\
\text { Long integer }\end{array}$ & $\begin{array}{l}\text { Nama Jabatan } \\
\text { Tunjangan Jabatan }\end{array}$ \\
\hline
\end{tabular}




\section{Tabel Golongan}

\begin{tabular}{ccll}
\hline Field Name & Data Type & Field Size & \multicolumn{1}{c}{ Description } \\
\hline Golongan & text & 2 & Primary key untuk Tabel Golongan \\
Tj_Nikah & number & Long integer & Tunjangan Nikah \\
Tj_Anak & number & Long integer & Tunjangan Anak \\
U_Makan & number & Long integer & Uang Makan \\
U_Lembur & number & Long integer & Uang Lembur \\
Asuransi & number & Long integer & Asuransi \\
\hline
\end{tabular}

\section{Tabel Gaji_Pokok}

\begin{tabular}{cccl}
\hline Field Name & Data Type & Field Size & \multicolumn{1}{c}{ Description } \\
\hline Kd_Jbtn & text & 5 & PK dan FK tabel Gaji_Pokok \\
Golongan & text & 2 & PK dan FK tabel Gaji_Pokok \\
Gaji_Pokok & number & Long Integer & Gaji Pokok \\
\hline
\end{tabular}

\section{Tabel Pegawai}

\begin{tabular}{lccl}
\hline Field Name & Data Type & Field Size & \multicolumn{1}{c}{ Description } \\
\hline NIP & text & 5 & Nomor Induk Pegawai \\
& & & Primary key untuk Tabel Pegawai \\
Nama & text & 30 & Nama \\
Alamat & text & 40 & Alamat \\
Tmpt_Lahir & text & 10 & Tempat Lahir \\
Tgl_Lahir & date/time (medium & - & Tanggal Lahir \\
& date) & & \\
Jns_Kelamin & Text & 10 & Jenis kelamin (Pria/Wanita) \\
Agama & Text & 10 & $\begin{array}{l}\text { Agama } \\
\text { (Islam/Kristen/Katolik/Hindu/Budha/Lainnya) }\end{array}$ \\
Pendidikan & Text & 5 & $\begin{array}{l}\text { Pendidikan } \\
\text { (TK/SD/SMP/SMA/S1/S2/S3/Lainnya) }\end{array}$ \\
Kd_Jbtn & Text & & Kode Jabatan \\
Golongan & Text & 5 & Golongan \\
Status & Text & 2 & Status \\
& & 15 & (Menikah/Tidak menikah/Duda/Janda/Cerai) \\
Jmlh_Anak & number (integer) & - & Jumlah Anak \\
\hline
\end{tabular}

\section{Tabel Absen}

\begin{tabular}{lccl}
\multicolumn{1}{c}{ Field Name } & Data Type & Field Size & \multicolumn{1}{c}{ Description } \\
\hline Bulan & $\begin{array}{c}\text { date/time (medium } \\
\text { date) }\end{array}$ & - & Primary key untuk Tabel Absen \\
NIP & text & 5 & PK dan FK tabel Absen \\
Jmlh_Hari_Masuk & number (integer) & - & Jumlah Hari Masuk \\
Jmlh_Hari_Sakit & number (integer) & - & Jumlah Hari Sakit \\
Jmlh_Hari_Izin & number (integer) & - & Jumlah Hari Izin \\
Jmlh_Hari_Alpa & number (integer) & - & Jumlah Hari Alpa \\
Jmlh_Jam_Lembur & number (integer) & - & Jumlah Jam Lembur \\
\hline
\end{tabular}




\section{Rancangan Layar}

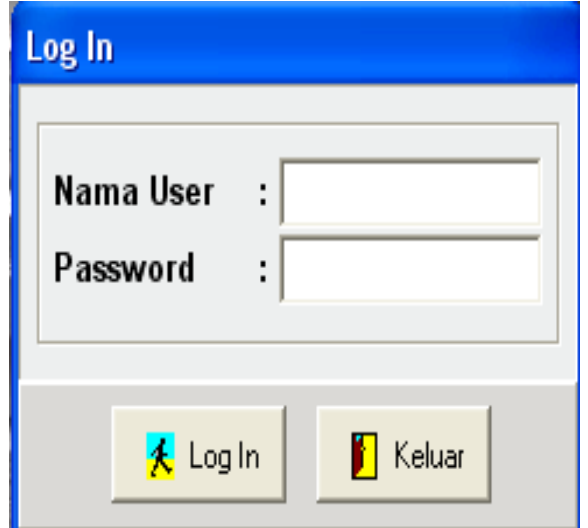

Gambar 5. Layar Menu Log In

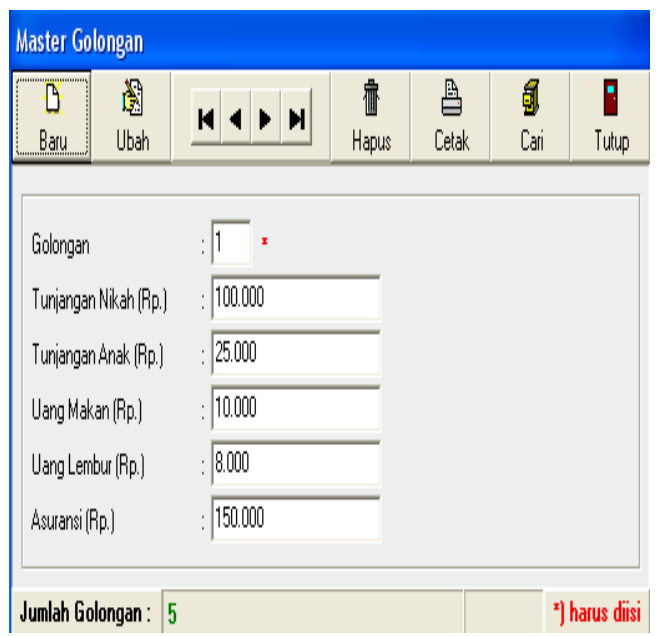

Gambar 7. Layar Menu File Master Golongan

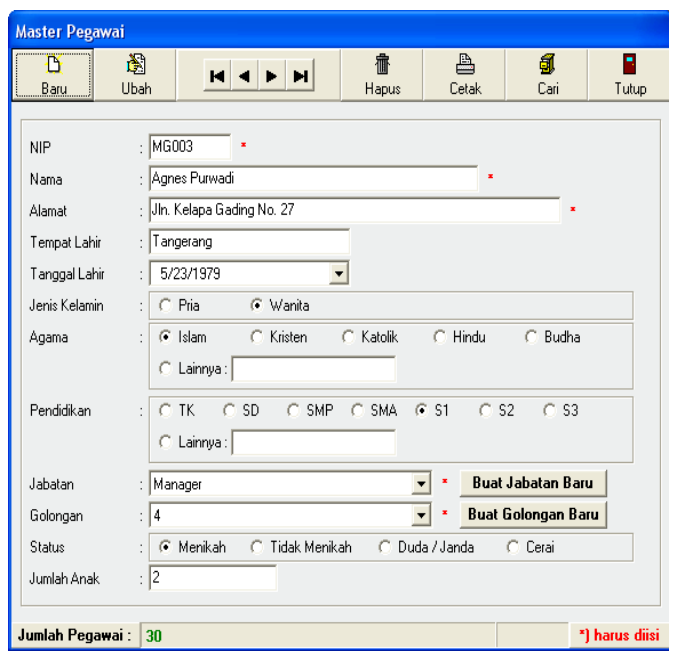

Gambar 9. Layar Menu File Master Pegawai

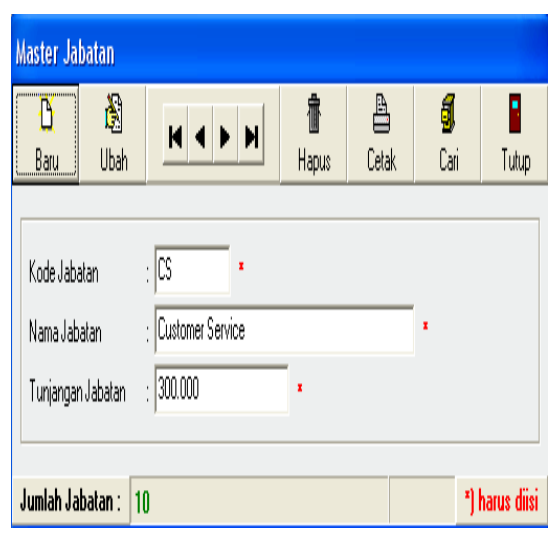

Gambar 6. Layar Menu File Master Jabatan

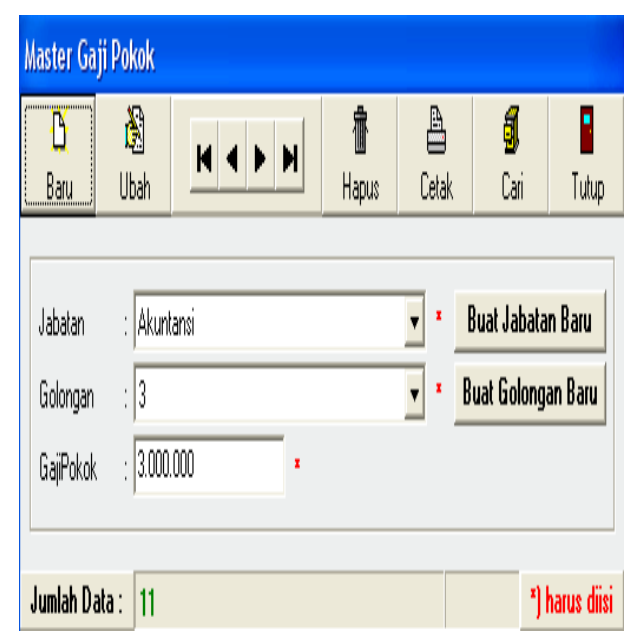

Gambar 8. Layar Menu File Master Gaji Pokok

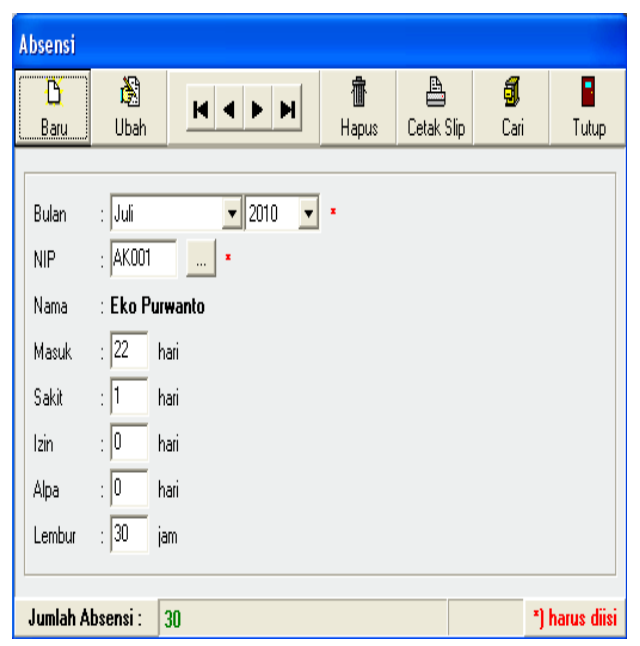

Gambar 10. Layar Menu File Absensi 
DAFTAR PEGAWAI

\begin{tabular}{|c|c|c|c|}
\hline 1. NIP & : AK001 & Agama & : Katolk \\
\hline Nama & : Eko Punwanto & Pendidk an & : s1 \\
\hline Tempat Lahir & : Surabaya & Golongan & $: 3$ \\
\hline Jenis Kelamin & : Pria & Jumlah Anak & $: 0$ \\
\hline 2. NIP & : AKO02 & Agama & : Kristen \\
\hline Nama & : Salty Don & Pendidk an & $:$ s1 \\
\hline Tgl Lahir & : 16/05/ 1972 & Status & : Menk ah \\
\hline Jenis Kelamin & : W'anita & Jumlah Anak & $: 1$ \\
\hline 3. NIP & : CLO1 & Agama & : Katolk \\
\hline Nama & : Liana Arumi & Pendidk an & : SMA \\
\hline Alamat & : Jln. Cililitan No. 111 & Jab atan & : Cleaning Senvice \\
\hline Temp at Lahir & : Jakarta & Golongan & $: 1$ \\
\hline Alamat & : Jln. W'ijay a No. 12 & Jab atan & : Cleaning Senvice \\
\hline Temp at Lahir & : Tangerang & Golongan & $: 1$ \\
\hline Tgl Lahir & $:$ 11/11/1978 & Status & : Menk ah \\
\hline Jenis Kelamin & : Pria & Jumlah Anzk & $: 2$ \\
\hline 5. NIP & $: \operatorname{cs} 001$ & Agama & : Elam \\
\hline Nama & : Juan Permana & Pendidk an & : SMA \\
\hline Alamat & : Jln. Karet No. 321 & Jab atan & : Customer Senvice \\
\hline Temp at Lahir & : Bogor & Golongan & $: 2$ \\
\hline Tgl Lahir & : 01/10/1965 & Status & : Menk ah \\
\hline Jenis Kelamin & : Pria & Jumlah Anak & $: 4$ \\
\hline
\end{tabular}

Gambar 11. Daftar Pegawai

Dicetak Tgl : 31/08/2010 10:53:34 PM

$\underline{\text { SLIP GAJI }}$

Juli 2010

\begin{tabular}{|c|c|c|c|}
\hline $\begin{array}{l}\text { NIP } \\
\text { Nama } \\
\text { Jenis Kelamin } \\
\text { Alamat }\end{array}$ & $\begin{array}{l}\text { : MG003 } \\
: \text { Agnes Purwadi } \\
: \text { Wanita } \\
: \text { Jn. Kelapa Gading No. } 27\end{array}$ & $\begin{array}{l}\text { Jabatan } \\
\text { Golongan } \\
\text { Status } \\
\text { Jumlah Anak }\end{array}$ & $\begin{array}{l}: \text { Manager } \\
: 4 \\
: \text { Menikah } \\
: 2\end{array}$ \\
\hline $\begin{array}{l}\text { Masuk } \\
\text { Sakit } \\
\text { Izin } \\
\text { Alpa } \\
\text { Lembur }\end{array}$ & $\begin{array}{lr}: & 23 \text { hari } \\
: & 0 \text { hari } \\
: & 0 \text { hari } \\
: & 0 \text { hari } \\
: & 12 \text { jam }\end{array}$ & $\begin{array}{l}\text { Gaji Pokok } \\
\text { Tunjangan Jabatan } \\
\text { Tunjangan Nikah } \\
\text { Tunjangan Anak } \\
\text { Uang Makan } \\
\text { Uang Lembur } \\
\text { Asuransi }\end{array}$ & $\begin{array}{r}6.000 .000,00 \\
1.500 .000,00 \\
250.000,00 \\
250.000,00 \\
322.000,00 \\
144.000,00 \\
-250.000,00\end{array}$ \\
\hline & & Total & $8.216 .000,00$ \\
\hline
\end{tabular}

Gambar 12. Slip Gaji 


\begin{tabular}{|c|c|c|c|}
\hline \multicolumn{4}{|c|}{ Dicetak Tgl : 31/08/2010 10:55:33 PM } \\
\hline \multicolumn{4}{|c|}{ LAPORAN KEHADIRAN } \\
\hline \multicolumn{4}{|c|}{ Juli 2010} \\
\hline NIP & MG003 & Jabatan & Manager \\
\hline Nama & Agnes Purwadi & Golongan & \\
\hline Jenis Kelamin & Wanita & Status & Menikah \\
\hline Alamat & Un. Kelapa Gading No. 27 & Jumlah Anak & 2 \\
\hline Masuk & 23 hari & & \\
\hline Sakit & 0 hari & & \\
\hline & 0 hari & & \\
\hline Alpa & 0 han & & \\
\hline Lembur & $12 \mathrm{jam}$ & & \\
\hline & & & \\
\hline & & & \\
\hline & & & \\
\hline
\end{tabular}

Gambar 13. Laporan Kehadiran

\begin{tabular}{|c|c|c|c|c|c|c|c|c|c|c|c|}
\hline \multicolumn{12}{|c|}{ Dicetak Tgl : 01/09/2010 8:17:04 AM } \\
\hline \multirow{2}{*}{\multicolumn{12}{|c|}{$\begin{array}{c}\text { LAPORAN GAJI BULANIAN } \\
\text { Juli } 2010\end{array}$}} \\
\hline & & & & & & & & & & & \\
\hline Ho. & HIP & Hama & $\begin{array}{c}\text { Jenis } \\
\text { Kelamin }\end{array}$ & $\begin{array}{c}\text { Gaji } \\
\text { Pokok }\end{array}$ & $\begin{array}{c}\text { Tunjangan } \\
\text { Jabatan }\end{array}$ & $\begin{array}{c}\text { Tunjangan } \\
\text { Nikah }\end{array}$ & $\begin{array}{c}\text { funjangan } \\
\text { Anak }\end{array}$ & $\begin{array}{l}\text { Uang } \\
\text { Makan }\end{array}$ & $\begin{array}{l}\text { Uang } \\
\text { Lembur }\end{array}$ & Asuransi & $\begin{array}{r}\text { Total } \\
\text { Gaji }\end{array}$ \\
\hline 1. & AKO01 & Eko Purmento & Pria & $3,000,000,00$ & $800,000,000$ & 0,00 & 0,00 & 264000,00 & $300,000,00$ & $.200 .000,00$ & $4.164,000,00$ \\
\hline 2. & AKO002 & Sally Don & Wanita & 3000000,00 & $800,000,00$ & $200.000,00$ & $75.000,00$ & 240000,00 & 170000,00 & .200 .00000 & $4285,000,00$ \\
\hline 3. & CL001 & Liana Anumi & Wanita & 1000000,00 & 100000,00 & $100.000,00$ & $75.000,00$ & $230,000,00$ & $40,000,00$ & .150 .000000 & 1395000,00 \\
\hline 4. & CL002 & Dari Tito & Pria & 1000000,00 & 100000,00 & $100.000,00$ & $50.000,00$ & 230000,00 & 96000,00 & $.150 .000,000$ & $1.426000,00$ \\
\hline 5. & $\operatorname{CS} 001$ & Juan Pemana & Pria & 1200000,00 & $300,000,00$ & $150.000,00$ & $13.000,00$ & $240,000,00$ & $45,000,00$ & $.175 .000,000$ & 1895000,00 \\
\hline 6. & $\mathrm{CSO02}$ & Jay Lim & Pria & $1200,000,00$ & 300000,00 & $150.000,00$ & 0,000 & 276000,00 & 0,00 & .175 .00000 & $1.751,000,00$ \\
\hline 7. & $\mathrm{CSO03}$ & Dariel Setiaman & Pria & 1200000,00 & 300000,00 & $150.000,00$ & $45.000,00$ & $264,000,00$ & $135,000,00$ & .175 .00000 & 1919000,00 \\
\hline 8. & $\mathrm{CS} 004$ & Joni Panjait an & Pria & 1200000,00 & $300,000,00$ & $150.000,00$ & $90.000,00$ & $240,000,00$ & 0,000 & $.175 .000,00$ & $1805,000,00$ \\
\hline 9. & DR001 & Eduard Pangestu & Pria & 8000000,00 & $2000.000,00$ & $350.000,00$ & 675.000000 & $460,000,00$ & $150,000,00$ & $.350 .000,00$ & $11.285000,00$ \\
\hline 10. & KS001 & Bayu Arasta & Pria & 1500000,00 & $700,000,00$ & $150.000,00$ & $13.000,00$ & 276000,00 & $135,000,00$ & $.175 .000,00$ & $2.721,000,00$ \\
\hline 11. & KSO02 & \begin{tabular}{|l} 
Indth Ariani \\
\end{tabular} & Wanita & 1500000,00 & 700000,00 & 0,00 & 0,00 & 228000,00 & 0,000 & $.175 .000,000$ & 2253000,00 \\
\hline 12. & KSO03 & Sherly Marischa & Wanita & $1,500000,00$ & $700,000,00$ & 0,00 & 0,00 & 264000,00 & $180,000,00$ & $-175.000,000$ & $2.469000,00$ \\
\hline 13. & MG001 & Ded Jo & Pria & $6,000000,00$ & $1500.000,00$ & 0,00 & 0,00 & 280000,00 & 60000,00 & .250 .00000 & 7590000,00 \\
\hline 14. & MGO02 & Liana Susanti & Wanita & $6,000,000,00$ & $1,500,000,00$ & $250.000,00$ & $250.000,00$ & $308,000,00$ & 0,000 & .250 .000000 & $8058,000,00$ \\
\hline 15. & MGO0B & Agnes P ưvadi & Wanita & $6,000000,00$ & $1500.000,00$ & $250.0000,00$ & $250.000,00$ & $322,000,000$ & $144,000,00$ & $.250 .000,00$ & 8216000,00 \\
\hline 16. & SD001 & Yasa $P$ aramitha & Pria & 3000000,00 & $800,000,00$ & $200.000,00$ & $150.000,00$ & $240,000,00$ & 0,000 & $.200 .000,00$ & $4.190,000,00$ \\
\hline 17. & $\mathrm{SD} 002$ & \begin{tabular}{|l|} 
Lita Zein \\
\end{tabular} & Wanita & 3000000,00 & $800,000,00$ & $200.000,00$ & $75.000,00$ & $264,000,00$ & $100,000,00$ & .200 .000000 & $4239,000,0$ \\
\hline 18. & SE001 & Jacqueline & Wanita & 2500000,00 & 700000,00 & 0,00 & 0,00 & 276000,00 & $50,000,00$ & $.200 .000,00$ & 3326000,0 \\
\hline 19. & SE002 & \begin{tabular}{|l|} 
Sheila Listi \\
\end{tabular} & Wanita & 2500000,00 & 700000,00 & $200.000,00$ & $150.000,00$ & 276000,00 & 150000,00 & $.200 .000,00$ & $3.776000,00$ \\
\hline 20. & ST001 & \begin{tabular}{|l|} 
Priyadi Santoso \\
\end{tabular} & \begin{tabular}{|l|} 
Pria \\
\end{tabular} & $5,000000,00$ & $1000.000,00$ & $250.000,00$ & $375.000,00$ & $322,000,00$ & 300000000 & $.250 .000,000$ & 6997000,00 \\
\hline 21. & ST002 & Bachtiar Rúm & \begin{tabular}{|l|} 
Pria \\
\end{tabular} & $5,000000,00$ & $1000.000,00$ & 0,00 & 0,000 & 308000,00 & $120,000,00$ & $.250 .000,00$ & $6.178000,00$ \\
\hline 22. & YTW01 & Anastasia Ariani & Wanita & 3000000,00 & $500,000,00$ & $200,000,00$ & $150.000,00$ & $240,000,00$ & $300,000,00$ & .200 .00000 & $4.190,000,00$ \\
\hline 23. & YT002 & Bagus Amri & Pria & $3,000000,00$ & $500,000,00$ & $200.000,00$ & $75.000,00$ & 276000,000 & $100,000,00$ & .200 .000000 & $3.951,000,00$ \\
\hline 24. & YT003 & Timoty & Pria & 3000000,00 & $500,000,00$ & $200.000,00$ & $75.000,00$ & $240,000,00$ & 0,000 & $.200 .000,00$ & 3815000,00 \\
\hline 25. & YT004 & Felipe Bare & Pria & 3000000,00 & $500,000,00$ & 0,00 & 0,00 & 264000,00 & $140,000,00$ & $.200 .000,000$ & $3.704,000,0$ \\
\hline 26. & YTO05 & Kevin Leonard & Pria & 1500000,00 & $500,000,00$ & $150.000,00$ & 0,00 & 276000,00 & 63000,000 & $-175.000,000$ & $2314,000,0$ \\
\hline 27. & YT०06 & Nia Yasmin & Wanita & 3000000,00 & $500,000,00$ & 0,00 & 0,00 & $264,000,00$ & 0,00 & $.200 .000,00$ & $3564,000,00$ \\
\hline 28. & YTळ07 & Riyand & Pria & 3000000,00 & $500,000,00$ & 0,00 & 0,00 & 240000,00 & 100000,00 & .200 .00000 & $3640,000,00$ \\
\hline 29. & YTि08 & Samsudin Eko & Pria & 1500000,00 & 500000,00 & 0,00 & 0,00 & 276000000 & 180000,00 & -175.000000 & $2281,000,00$ \\
\hline 30. & YTO09 & Bud Sam & Pria & 3000000,00 & $500,000,00$ & $200.000,00$ & $150.000,00$ & 264000,00 & 300000,00 & .200 .00000 & $4214,000,00$ \\
\hline \multicolumn{4}{|c|}{$\begin{array}{l}\text { GRAIID TOTAL } \\
\end{array}$} & $88300,000,0$ & $21.100 .000,00$ & $3.900 .000,00$ & $2900.000,00$ & 8148000,00 & 3388000,00 & $-8075000,00$ & $121.011000,00$ \\
\hline
\end{tabular}

Gambar 13. Laporan Gaji Bulanan

\section{PENUTUP}

Berdasarkan pembahasan yang dilakukan sebelumnya dan hasil analisis dan perancangan sistem informasi penggajian maka dapat disimpulkan beberapa hal sehubungan dengan sistem informasi perusahaan. Pertama, pencatatan yang dilakukan secara manual, karena perusahaan tidak menggunakan sistem aplikasi yang terkomputerisasi, maka dirancanglah sebuah sebuah sistem 
informasi yang berbasis komputer yang dapat menangani kelemahan-kelemahan tersebut, sehingga sistem informasi penggajian akan menjadi lebih efektif dan efisien. Kedua, sistem informasi penggajian yang dirancang dapat mengatasi masalah human error dalam penghitungan berbagai komponen gaji dan upah yang ditetapkan oleh perusahaan dan dapat menghasilkan informasi penggajian yang akurat dalam bentuk laporan kehadiran karyawan, slip gaji, laporan kehadiran karyawan, laporan daftar pegawai bagi pihak manajemen. Ketiga, adanya pembatasan hak akses sehingga menghindari pihak-pihak yang tidak berwenang untuk dapat mengakses data. Saran yang dapat diberikan adalah sebagai berikut. Pertama, sebaiknya dilakukan pelatihan terhadap karyawan yang akan menangani sistem informasi penggajian. Kedua, dilakukan backup data secara berkala untuk menjaga informasi agar dapat digunakan sebagaimana mestinya. Ketiga, bagi peneliti berikutnya dapat mengembangkan perancangan sistem informasi akuntansi penggajian dengan memasukkan pajak penghasilan karyawan, sistem informasi akuntansi pembelian dan persediaan pada perusahaan ini.

\section{DAFTAR PUSTAKA}

Haryanto, I. (2004). Membuat database dengan Microsoft Office Access. Bandung: Informatika.

Horngren, C. T., Harrison, W.T., Bamber, L.S., (2002) Accounting, Fifth Edition, New Jersey: Prentice Hall International Inc.

Jones, F. L., Rama, D. V. (2006). Accounting Information Systems. International Student Edition. Canada: Thomson South-Western.

Mathiassen, L., Madsen, A. M., Nielsen, P. A., dan Stage, J. (2000). Object Oriented Analysis \& Design. Edisi 1. Denmark: Forlaget Marko.

Mulyadi. (2001). Sistem Akuntansi, Edisi 3. Salemba Empat. Jakarta

O’Brien, J. A., \& Marakas, G. M. (2006). Management Information System, Seventh Edition. New York: McGraw-Hill.

Mou, R., \& Kleiner, B. (2006). Duty of care involving outsourced payroll. Information Management \& Computer Security. Bradford. Vol. 14, Iss. 3; pg. 284

Warren, C., S., Reeve, J. M., \& Fess, P. E. (2002). Accounting, Twentieth Wdition. Ohio: Thomson South-Western. 